\title{
Knowing the Place for the First Time: A Cuban Exile's Story
}

\author{
Alejandra Moreno and Roberto Milanes ${ }^{1}$
}

\begin{abstract}
And know the place for the first time.
And the end of all our exploring

Will be to arrive where we started

And know the place for the first time.
\end{abstract}

TS Eliot 'Little Gidding'

Marta Gómez lived with her parents and her two elder sisters in the suburb of Vedado, Havana, Cuba. Her mother held a $\mathrm{PhD}$ in psychology, her father was a doctor. She attended an exclusive girls' school, managed by the Sabina order of nuns, known as Las Sabinas. Her classmates were largely the children of bureaucrats, politicians and senior civil servants. Marta — had there been no Revolution, she was ten years old at the timemight have expected a life of material prosperity, higher education and a professional career. And a sense of belonging to a land she could confidently call 'home.'

Married to her mother's sister, Marianita, was the property developer Pepe Postino. He lived with his wife and their two sons Ricardo and Julito in the more up-market suburb of Biltmore. Pepe admired the know-how and the standard of living of North Americans and possessed the money to acquire it. Half a dozen times a year he visited his land of deep admiration, by plane, by ferry, or in his own cruiser. Living in a politically unstable nation, he knew that his continuing support of President Fulgencio Batista's regime

\footnotetext{
${ }^{1}$ Alejandra Morena is a pseudonym. She works in modern Australian history, and on contemporary Cuba and Chile. Her publications are in the fields of memory and memorialisation, custodianship of place, and trauma and reconciliation. Roberto Milanes is a pseudonym. He works in Australian Aboriginal history, and on contemporary Cuba and Chile. His publications are in the fields of trauma and reconciliation.
}

PORTAL Journal of Multidisciplinary International Studies, vol. 6, no. 1, January 2009.

'The Space Between: Languages, Translations and Cultures': Special Issue edited by Vera Mackie, Ikuko Nakane, and Emi Otsuji. 
carried the threat of retribution in the event of yet another change of government. Politically astute Havanans like Pepe understood well enough, years before Fidel Castro's open declaration of communism in 1961, the inclinations of los barbudos, the bearded ones, the rebels. The astute also knew, or thought they knew, that there was no way in which the United States government would permit a red rebellion to topple President Batista, unpopular though he was. A mansion in the top suburb, prestige, fine cars in the garage, were worth the risk of a brief coup d'etat by the undeclared communists. Pepe's family looked forward to a life of ever-increasing prosperity and material well-being. In 1953 Pepe himself was looking for ways to invest outside the city.

An hour away on the coast to the west, in a quiet fishing village called Palo, lived two young people in their twenties. They expected in their lives the achievement of basic necessities rather than prosperity. The main road to Varadero - the famous beach resort of the Cuban and North American rich-was not far from the town, but few people in their own village possessed cars. While only one or two people in the village had ever been to Havana, the endemic political and financial corruption affected them all. The names of these villagers were Felipe and María. They looked in the 1950s newspapers at the advertisements for North American cars, buildings, domestic appliances. They heard on the radio about television, but nobody owned one, and only one person in the town claimed to have ever seen one. If one worked hard, and kept working, the rewards of rural village life were available to all: pigs, goats, a rooster, a donkey, a home, a family, a secure community.

Ten kilometres from Palo lay the dazzling sands of a secluded area known as Playa Abierta: a protective bay, a narrow coastal strip, a high eroded cliff, a sumptuous hinterland. In 1954 nobody lived there save a few fishermen and their families, but the area had been visited for centuries. Fifty metres above the coastal plain of Playa Abierta was a deep and mysterious cave. From sacred sites like this, it was believed by Cuba's indigenous people, the sun, the moon and humankind had taken their origins.

At about the same time as Felipe and María reached their mid-twenties, Pepe Postino found his rural hideaway at that Playa Abierta of bay, beach and sacred cave. In 1955 he and his consortium bought some 1,000 acres, primarily, in his mind, as a development investment. But soon Pepe was gripped by the notion of his own estate in which his family would spend their weekends, and where, ultimately, a whole community of 
kindred spirits might live in safety and splendid isolation. Developing the estate as his private paradise became his obsession. Throughout 1956, leaving Havana on Thursdays, he would be on the headland an hour later to plan, direct, employ and build, until Saturday when his wife Marianita and the boys arrived. 'Sombra' (Shadow), the small cottage built to house the family on visits to the site, was their first foothold in Playa Abierta. The family selected the best view for what was to be their own, much grander, house to be designed by the best Miami firm of architects from the latest materials. Once installed in the big house, Pepe bequeathed 'Sombra' to Marianita's sister, her husband and the three girls Laura, Ada and Marta Gómez.

'Sombra' lay on the western end of the beach and across the creek, where Pepe planned the dwellings he would build for close family and friends. Just here would be a house for Elena, his mother, just behind it, the cottage of her servants; over there would be the home of his sister Elenita. Further away and above the narrow coastal plain would be placed the holiday houses for sale to the North American and Cuban company executives of Gillette, Coca-Cola, Pepsi and Materva. Pepe's plans widened in proportion to his energy and enthusiasm. Month after month he and Marianita travelled to Miami to select furnishings from the best of the North American way of life and its technology, material richness implanted upon the breathtaking scenery of Playa Abierta. For those who could afford it, a love affair with the United States epitomised the Cuban 1950s. The adults had the verandas, the beach, the fine cars, the cruisers. Children had volleyball and baseball on the beach, ping-pong and swimming in the house. Pepe's son Ricardo, aged eleven, was given a golf cart to take him and friends on joy rides around the estate; Julito got a Mercedez Benz for his sixteenth birthday.

Everyone got rides in the golf cart and 'Merceditas,' as Julito baptised his new sportscar. Ricardo was my age and often a few of us would pile into his toy-car, whizzing around the sand and the bushes, with no one to spoil the fun. Playa Abierta's borders were invisible but impenetrable. They reassured the adults, and liberated us to be children, such as we could not be in our troubled city.

For now, in the midst of his 1956 development, arrived news that Castro's tiny rebel forces had landed in Oriente Province and were conducting a guerilla war from the mountains. Oriente was about as far as one could get from Havana; more worrying to the better suburbs of Havana was their success in raising revolutionary cells amongst workers, activists and soldiers much closer to the capital. Marta's father, who together with Pepe 
had already spent two periods of self-imposed exile abroad, did not have the confidence of his brother-in-law, and preferred to invest in bonds and shares and keep his assets fluid.

Political assassinations were becoming more common.

I remember overhearing conversations that suggested my father and Pepe might be the targets of retaliation. Both were men of considerable wealth, and had been approached to make donations to the revolutionary cause. Or else. It was blackmail and they knew it. I remember their outraged voices. Of course they would not contribute to the downfall of Cuba! That would be treason! I also remember my mother's and Aunt Marianita's support of their menfolk: how dare those rebels threaten their machos. These were instructive lessons for a young Cuban girl to learn. At the time I just thought they were all so brave, though I worried for my father's and Pepe's safety.

Through 1956 political life grew steadily unstable. In 1957 Castro's local cell of supporters tried to storm the presidential palace, and though they failed to take it, Batista's government remained tense.

I don't ever recall a time in my childhood when the political did not intrude into our personal lives. Both my father and Pepe had held high offices in a previous government. They had made large gains as well as powerful enemies and had twice to leave the island for short periods. Exile was among the first words I learnt as a child! Many of my early childhood photographs are set in Mexico and in Miami: not on vacation, but on family reunions visiting my father and Pepe. As the Revolution gained momentum across the island, a new threat - and the possibility of yet another exile-loomed large. Escaping those tensions was impossible. At home the conversations often revolved around 'the situation.' And increasingly 'the situation' assumed personal dimensions: a friend of my father's was assassinated while enjoying a cabaret show at Tropicana; suspicions that some of the domestic staff harboured revolutionary sympathies and could turn on the family when the barbudos came down from the mountains.

Las Sabinas reflected the tensions, for the possibility of the kidnapping of children could never be ignored.

At school, the same thing. Several of my classmates came from families even more politically involved than my own. One was the daughter of the Chief of the Armed Forces; another, the daughter of the Head of Police. The pecking order was all too clear when - as it increasingly happened through the late 1950s-a crisis somewhere in the city would prompt the unexpected arrival of the family chauffeurs: on instructions to get us home to safety as quickly as possible. Over the intercom came the voice of our Principal, calling for us-one by one-in order of our fathers' political rankings. I was usually called third.

The crises mounted. A popular student leader was shot on the steps of the university. 
Every week brought news of attacks or ambushes.

Worse still were the suspicions of extended family members 'crossing over' to Fidel's side. I remember my mother's and Marianita's outrage: a terrible sense of betrayal that lingers unspoken but unforgiving in family circles to this day. Above all, this blurring of the lines of loyalty meant the enemy was everywhere; the next ambush might be just around the corner. My sister's fifteenth-birthday partyprincipal rite of passage of well-to-do Cuban girls and typically a sumptuous occasion in which a family's social standing was showcased extravagantly with live orchestras and a guest list of hundreds - had suddenly to be dramatically downsized: a smaller venue, fewer guests, high security. The fear of ambush, kidnapping, even assassination was everywhere.

Meanwhile at Playa Abierta the few inhabitants of the beachfront fishing village had been forcibly relocated to Palo: this was now private property. Pepe needed labour. Felipe was recruited as a handyman; later, when Pepe's new house on the headland was occupied, he became one of Pepe's 'watermen' in charge of keeping the tanks full. María's first employment on the estate began as soon as Pepe completed a house for his mother: she became one of several of Elena's maids who would remain in residence, in their own modest cottage, whenever the Señora returned to Havana.

By 1957 the houses, the new road to Varadero and Playa Abierta and most of the infrastructure of the settlement were complete. To show his gratitude to Batista for diverting the road near his property, Pepe threw one of the prodigious parties for which he and Marianita were famous in the city. President Batista came, the press reported it excitedly, photographs of Pepe and Batista adorned the walls of the Playa Abierta mansion. After the triumph of the Revolution on the first of January 1959 this close association between developer and disgraced president was not forgotten.

Marta's family came to stay on most weekends. Her most treasured memory from her eleven years in Cuba is of a stroll on Pepe's beach sucking a mango juice through a straw. Life seemed so secure that it seemed that Pepe's world must last forever.

Weekend and holiday visits to Playa Abierta were the highlights of my last three years in Cuba. Routine as they were, I never took them for granted. Not because I sensed its impermanence-none of us did-but because it meant escape from the political tensions in Havana. It was such relief to leave Havana behind and know that the guardhouse to my uncle's estate awaited us, with its promise that everything beyond that point was protected and safe. No harm could come to us in Playa Abierta. The gods would not allow it. 
In Playa Abierta, I was free to roam on my own, walk barefoot on the sandy beach, explore the bushland, lose myself in a world diametrically opposed to my regimented, over-protected life in Havana. I could never walk the streets of my city: even to school, a few blocks away from home, we were driven by our chauffeur. No wonder on my first return visit to Cuba, I could not find my way around even the most familiar places. It was only in Playa Abierta that I really set foot on the land of my birth, directing my own steps, enjoying a sense of belonging such as I never had in Havana. I think my relationship with Playa Abierta was forged above all in gratitude. It gave me a chance to grow and to fall in love with Cuba on my own terms. I don't know that I ever thought beyond the present in those days; the present was complicated enough for a child to absorb. But I know that I carried with me the conviction that Playa Abierta was mine forever: the impromptu cruises in my uncle's yacht when family and friends would come together for a day's fishing expedition; the volleyball games with a mobile community of young people who seemed to just drift in and out; the horseback rides, the picnics. My sisters, eight and nine years older than me, engaged in big-girl activities: canasta games with their friends, playing romantic Cuban boleros and sharing intimate chats about boyfriends. I was the spectator, but those vicarious experiences fed me a sense of my tomorrows in Playa Abierta. That's what it would be like for me in a few years' time. That would be me at fifteen and sixteen years old, and beyond. I could almost touch that me: she and her future seemed so real, so clear, so secure then.

Playa Abierta and its possibilities fired Pepe's imagination. The workers were busy with the cobbled roads and concrete gutters, the new cottages, the stone water tower, and a concrete pier for the boats and to hold the sand in place. No churchgoer himself, Pepe built a chapel for Playa Abierta's growing community of fellow holidaymakers and anyone in his large workforce who wished to attend. On the highest point of the cliff above the chapel Pepe constructed the bell tower, la campana, to sound the new year and as a focal point for his visitors. Beside it his work brigade constructed a folly for picnics, a summer house with little paths and unexpected seats to catch the panorama extending twenty kilometres east and west. Pepe's tours of his estate always ended here as a kind of pilgrimage to beauty and achievement. Today the view is as splendid as ever. Most of today's photographs advertising the pleasures of Playa Abierta are taken from this vantage spot.

Pepe fashioned himself as a latter-day feudal lord, extending largesse to his workforce on special occasions. Marta remembers him in a Santa Claus suit and white beard, dispensing Christmas presents to all the children of his workers: big American dolls for the girls, boxing gloves and baseball bats for the boys. Indeed, Marta now marvels at how much US culture flavoured that world. It was not simply the material and professional resources used to design, create and furnish Pepe's imposing mansion on the hill. Special 
family occasions were typically a seamless combination of the Cuban and the North American. The floor-to-ceiling Christmas tree that was the centrepiece of the Playa Abierta family living room at Nochebuena revolved to the tune of Jingle Bells and Silent Night. A surprise eighteenth birthday party organised for Pepe's son featured a special performance borrowed from Bing Crosby's recently released movie 'White Christmas.'

The landlord's extravagance grew. For Marianita's surprise fiftieth birthday party a hundred guests hid in the garden. In the distance Marianita thought she heard a band playing. Chinito, ¿qué pasa? —asked Marianita of Pepe-what's happening? Up rumbled a flat top truck containing La Riverside, Havana's top dance band. Everyone jumped out of hiding, the party lasted till dawn, in Marta's memory, only ending in most of the guests dancing a conga into the swimming pool!

I have been to many extraordinary parties in my life: from embassy balls to wedding receptions set in some of New Zealand's most magical landscapes. But they all fade into shades of gray in comparison to Marianita's fiftieth birthday party. It's hard to know whether it's the child's imagination that refuses to yield ground to the adult's experiences, colouring everything that happened that day brighter, more intense, more beautiful than anything could ever be again. Or whether it was as I remember it: an occasion unrivalled in elegance and style, but especially in boundless Cuban joy. The sight of those women, in their long gowns and diamond necklaces, slipping away graciously from their conga line into the sparkling blue waters of Pepe's pool, with no care for their coiffeurs or their makeup, thrills and haunts me to this day. Was I really part of such a moment in time-and in place? The world I've got to know since makes me wonder if I haven't imagined it all. Playa Abierta bequeathed us many things. Among them is a stubborn sense of anticlimax that will not budge.

Remote though Playa Abierta was, in those uncertain days of 1957-58 security had to be maintained. Pepe's family's dwelling was the only one constructed on the eastern side of the beach, protected by an armed guard. Pepe kept one of his two cruisers always at Playa Abierta, for pleasure-but also for an emergency evacuation, allowing two means of hurried egress should the need arise. On the lofty heights above the beaches, he allowed Batista's troops to carry out manoeuvres and coastal surveillance, and to construct a massive concrete bunker for their equipment.

Throughout 1958 Castro's barbudos were fighting their way, in street fights, cells and propaganda from the Oriente mountains. Overwhelmingly Cubans supported rather than opposed them. The loyalty of much of the government army was at best doubtful. By mid 
December Havanans were asking themselves when rather than if Batista's government will fall. There were few regrets; he was much hated.

But the Nochebuena (Christmas Eve) of 1958, a mere week before the revolution, still delights the memories of those who to this day discuss it in Miami.

Nochebuena 1958 had a special quality about it. In retrospect, it's tempting to think that, like passengers in our own Titanic, we must have known the end was near. But I don't remember it like that. Sure, 'the situation' was grim and life had become a series of newsflashes about the latest outrages perpetrated by the barbudos on innocent Cubans: my family's version of what was happening. But since the advent of the republic, Cuba had confronted many such crises before and somehow overcome them. Besides, the Americans knew what was going on and would not allow a communist revolution to succeed. Not our friends, the Americans. Such thoughts were reassuring, and I think they made the adults feel better. All was well. Uncle Sam was in charge. Whether the adults knew more than they admitted to usor to themselves - it's hard to know; or whether perhaps with the passage of time, we have collectively chosen to remember that time through rose-coloured glasses: who knows? But that last Christmas in Playa Abierta is now enshrined in the family mythology as a gift of the gods, the gods who knew better, yet still chose to protect our innocence: one last time.

That December 24 the whole community came together to attend midnight mass - la Misa de Gallo. Adults and children and staff formed a candle-lit party procession towards the chapel, carolling. The scent of the uva caleta bushes and the candles, the wash of the sea, the soft Cuban night, the exciting tales of the Green Monster who haunted the small lagoon at the foot of the chapel, the Spanish carols: they still dwell vividly in a memory fifty years old.

\footnotetext{
Esta noche es Nochebuena

Vamos al monte, hermanito, A cortar un arbolito

Porque la noche es serena ...

Tonight is Nochebuena

Come to the hills, little brother,

To cut a Christmas tree

For the night is serene ...
}

The last carol sung, the last present unwrapped, the last turn of Pepe's Christmas tree as it plays Jingle Bells for the hundredth time that night. The curtain is coming down on Pepe's Playa Abierta and still the family lingers. 
There was now no getting away from the fact that 'the situation' had reached crisis point. Pepe pondered the deteriorating position. He knew well enough that the first few months after any coup d'état were good times for sympathizers of the old regime to be absent! Not wanting to be caught out of range of instant news, Pepe and Marianita for the first time in three years held Año Nuevo, New Year's Eve, not at Playa Abierta, but in their city mansion at Biltmore. It is 31 December 1958.

The end came quicker than anyone imagined. Though the rebels were still at some distance from the capital, it was clear that the regime could not last. The story runs that Batista was celebrating the new year at the Havana Hilton (now the Habana Libre). The guests crowded the terrace to admire the midnight fireworks, which, unaccountably, lasted longer than they should. Unease gripped the party: these were not fireworks, but gunfire! By three am on the first of January 1959, President Batista abruptly abandoned his government by helicopter to the Dominican Republic, thence to the Canary Islands where he remained for the rest of his life. The city was overjoyed. Pepe rang Marta's father to warn him of Batista's departure. By four a.m. Pepe's escape plan was operational. He would leave his Havana and his Playa Abierta by the dawn ferry to Key West in Florida.

Was it escape, flight, dignified departure or protest? Marianita's interpretation of these rushed events is that her husband certainly did not flee: he already had a ticket to Miami postponed until after the new year, and did not want to be caught in the crossfire. It is a question of male pride. No, her man was not fleeing out of cowardice, but convenience. Exile has a long and honourable history among Cubans, and is the only course for any self-respecting Cuban man in the face of an oppressor. But the idea of the US government allowing a communist movement to take control over the island was unthinkable. To his family, Pepe was thus neither a fugitive nor an exile. The first would have been unmanly, the second would have granted the barbudos a status they did not deserve.

Whatever one's interpretation, the revolution had come so fast that transport services were still normal, but soon enough that everyone in the city was aware of their president's unseemly departure. Pepe took his Cadillac and light baggage. He had packed in a hurry and with the absolute certainty that his absence would be a matter of days or weeks, until the U.S. Government sent in the Marines to 'sort out the mess.' The ferry drew him away from his birth country. Arriving at Key West a few days later he was 
greeted derisively, this time by exiles from Batista's government now preparing their triumphant return to Revolutionary Cuba. Pepe told his family, 'I'll be back next week,' but he never saw Cuba again. The perennial toast of the Israelites, 'Next Year in Jerusalem,' became 'Next Year In Cuba' for the growing exile community in Miami. For Pepe and his family, the toast would always be the same, 'Next year in Playa Abierta.'

It was probably only a few days later, and via the remaining servants, that Felipe and María heard the news of Pepe's departure from Havana. Their memories of three and a half years of excitement with their volatile employer they held in silence.

Before long Castro's soldiers arrived in Playa Abierta and Pepe's house was locked. By the end of January the estate was looking drab, weeds were starting to overgrow the roads, the chapel was empty and the bell silent. Like many of the former staff, Felipe and María wondered about the family's return, which they knew was not likely while the revolutionary government remained in power. Yet the phones stayed open. Pepe kept in touch with several of his old employees - especially his boat crew David and Francisco. In Revolutionary Cuba, Playa Abierta and its proprietor symbolised the privilege and corruption of the old regime. The Indonesian president Sukarno stayed in Pepe's house in 1959, but the newly installed Cuban President Manuel Urrutia, showing what a good socialist he was, refused to enter that icon of bourgeois indulgence, and stayed instead in Elena's house.

Marianita chose not to join Pepe in Miami but remained in Havana, while Pepe rang to say that it might be another week or two. The confiscations of property, the imprisonment and execution of Batista supporters continued.

\section{The first return}

Towards the end of January, when things did not look like getting resolved that quickly, Marianita decided to visit Playa Abierta. She took Julito with her for moral support. I just went for the ride. Partly, I guess, Marianita wanted to reassure herself that it was business as usual in Playa Abierta, and partly she wanted to send a message to the revolutionary government that the family's hold on the estate was unwavering. She is a very tough lady and I don't remember her at all frightened that day. She was coming home and God help whoever stood in her way. But the early warnings of what awaited us came as we approached the coastline of Playa Abierta. It was devastating. Clotheslines, intimate clothing and rubbish lay everywhere about the beach. This was not the beautiful pristine Playa Abierta we 
had left a mere month ago. It was like a horde of barbarians had been let loose here. The guardhouse, we noticed, was empty. Approaching the Big House, we saw the unkempt garden, and more ominously, Felipe, Maria and the other staff were nowhere to be seen. We approached the front door. Marianita was in a rage and wanted explanations. Her key to the house no longer worked. She knocked on the door and there in front of us was Raquel, one of Marianita's personal maids of many years, blocking our entrance. There was no respectful greeting, as in the old days. Instead Raquel uttered the words that have resounded in every revolution in every age and in every country, Señora, ésta no es tu casa. 'Madam, this is not your house, 'followed by the sound of a slamming door. It would not open again for us.

All the way back to Havana, I remember that all Marianita could do was to recount the many favours she had done to these people, the many times she had come to their families' aid. 'These people pretended to be part of the family,' she repeated over and over again. All she could see was their betrayal. And I understood her. There was in Cuba a certain understanding between master and servant that softened the edges of that relationship and gave both sides a glow of reassurance that, despite the obvious differences in status, we were all family. They looked after us and we looked after them. Marianita felt she had fulfilled her side of that contract and for what?

Marianita's forced retreat was the very last visit by the family to their sacred beach site.

The revolutionary government commandeered Pepe's Havana cruiser for pleasure trips by Dr Urrutia, the new President of the Republic, and sent Marianita the bill for the fuel. Pepe grew increasingly anxious. His faithful boat crew-David and Francisco-now became the family's lifeline as to what was happening in Playa Abierta.

Vowing vengeance, Marianita returned to her Biltmore mansion in the city, where the prognosis was worse. At any moment the police or the militia were likely to arrive to count the number of inhabitants of the house while warning her that big houses like hers were needed urgently for schools. Marta, her two unmarried sisters and her mother left their rented property to offer mutual support. With her eldest son nearing the age of the army draft, and with Marianita as the wife of the despised Pepe Postino, it was clear that some of his family at least were at increasing risk of arrest, his house and goods of confiscation. Ten months after the revolution, in October 1959, the boys hurriedly were bundled on to a plane to the United States. Marianita herself followed two months later. Marta's family left in April of the following year. Of all that she left behind, the little girl mourned her beloved stuffed rabbit that she was not allowed to bring on the plane. It will be there when we get back. 
Those last few months that we shared together at Marianita's house in Havana were terrible at the time but have become very precious since. I was the youngest there, and my sisters and cousins were too busy with their own lives to pay much attention to me. What I remember most of that time were the two womenMarianita and my mother-and the magnificent way in which they carried themselves throughout this crisis. With their men away, it fell on them to protect everything they held dear: their families, their properties, their honour. It was all under threat. And every time one of the militia groups paid us a visit and started probing into the number of occupants and the number of rooms in the house-a clear signal that they were thinking of requisitioning the place any minuteMarianita and my mother stood firm. They lied and wove fanciful stories of more family to come, they invented 'high officials in the government' whom they knew intimately and would not be impressed to hear that they and their families were being harassed in this way. They gave their visitors lessons on Cuban history and the true meaning of patriotism. They preached to them about respect for their elders and for the sanctity of the Cuban family. They appealed to their machismo by portraying themselves as women-in-distress. In short, they both manipulated them and exhausted them. The house and staff remained Marianita's for some time after we had all left for Miami.

For me, it was a wonderful lesson in Cuban womanhood. It taught me that the word 'macho' does not exclusively relate to the male, but to those gender-free virtues of courage, dignity and honour that we Cubans value so much. I resolved to be a 'macho' during those difficult months: a vision that would never have occurred to me if my previous world had not been turned upside-down just a few months before, and circumstances had not offered me role models like Marianita and my mother. Not everything that I endured in Revolutionary Cuba was a nightmare. Some experiences proved very precious indeed.

Now reunited with his family in Miami, Pepe Postino continued to believe that it could not be long before Castro fell or was overthrown. When the Bay of Pigs invasion failed in 1961, he raged and plotted. It was rumoured that Che Guevara himself had taken up residence in the Big House at Playa Abierta. Pepe considered hiring someone to fly to Playa Abierta and bomb the place. Marianita prevailed upon him that this course was much too dangerous, then hit on a better plan. Why not get David and Francisco, their boat crew still in the island, to break into the Big House, pack Pepe's cruiser with as much of the house goods as they could fit in to the craft-and sail it to Miami? They did so to a heroes' welcome-before returning to their birthplace. The champagne bottle from which a toast to the downfall of the regime was drunk at Julito's wedding became a family icon.

Today Marianita's dearest pleasure is to walk around her apartment identifying the silver, the glassware, the objets d'art: They came over on the boat! 


\section{The second return}

For all the family's intimate connections with Playa Abierta-or perhaps because of them-it was, and is considered a family disgrace that any of us should re-visit Cuba while still under Castro's rule. My sisters especially see it as nothing short of betrayal of 'the cause' and have wanted nothing to do with my plans to re-visit the island. Only the fact that I have lived in New Zealand for over a quarter of a century has helped to explain — not excuse-my behaviour. As my Miami family chooses to see it, New Zealanders are too far away and too enamoured with socialism to appreciate the realities of Castro's Cuba.

Nonetheless, in January 1996, Marta became the first — and so far the only-member of her family to re-visit, or as she puts it, to reclaim, her uncle's estate Playa Abierta. She travelled by taxi through Palo, down the Via Blanca to the entrance to Pepe's house. A guard denied her entry, for the building was, he said, occupied by soldiers. Her determination only grew. She would find another way into the Big House. She crossed the concrete road bridge spanning the Playa Abierta creek to leave the area of the family houses, now operated as a tourist resort by a French consortium. This was the former entrance to the beach.

At one point, I was not sure I was in the right place: the sand had been grassed, houses had been added, old houses 'improved.' To me the guiding star was Pepe's house: set high on the hill: hugging the landscape. This was the heart of Playa Abierta. It was not until I stood on the edge of that creek that I looked up to find the house: unmistakably 1950s ultramodern. I swam across the 200-metre channel impelled by forces I had no idea I harboured. There was electric wiring all around. Whether it was live or not I didn't know and didn't care. Then I walked across the beach and found a cluster of large rocks that I climbed. At the other end lay the foot of the long staircase that I knew led to the house. And there it was. I reached the top and looked to the left to confirm that the house stood as I remembered. I decided to approach it through the front door more as an act of defiance than anything else. I was going to help myself to Pepe's house as I always had. I did not need permission from the usurpers to enter our family's sacred site.

It was indeed a military establishment. My uncle's house had evidently been turned into a rest and recreation camp for junior officers. Notice boards as I entered announced the day's activities: billiards, and swimming. I looked to the left-the living quarters where my uncle and aunt, and my two male cousins each had their rooms looking down on the beach head. The walls were torn, the rooms were locked. No sign of life here. I turned to the right: the dining room, where our Christmas dinners had been had, filled up with more notice boards. The kitchen was locked. This was no family residence any more. I walked down the set of stairs that led from the dining room down to the large living room. Gone were the large bear and tiger skins that had covered much of that floor space, and instead of the old familiar setup of lounge chairs were two billiard tables and a juke-box going flat out. At one 
table were two men playing billiards, while women outside played with small children in the filthy and half-empty pool. I had walked through the house and reconquered this space unannounced and uninvited! As I went to leave by the door I knew so well one of the soldiers put his cue across the exit to stop me. I stood and waited for him to remove it. I knew that if I opened my mouth, my Cuban-Miami accent would betray me. I resolved to remain calm and say nothing. His colleague, anxious to get on with the game, told him to let me pass.

Impossible to describe the feeling as I left Pepe's house! It was unspeakable joy and sweetest revenge. After thirty-seven years of family rage and mourning over what we had lost, I had repossessed the place with a glance-the sheer fact that I was there had conferred ownership on it.

In Havana I was the little girl returning to visit the country of my childhood. In Playa Abierta I was the son repossessing for my family our stolen land.

\section{The third return}

Marta has revisited Playa Abierta several times since January 1996. A guard remains at the entrance to Pepe's mansion, still protecting the junior officers resting and recreating. There are now barbed wire entanglements in place making it impossible to enter from the seaward side. She likes to think that this was prompted by her clandestine visit and a belated alarm raised by that unknown woman-dripping wet and with hair and clothes soaked with sand-who was last seen leaving the house and the grounds as if she owned the place.

In 1998, on her third visit to Playa Abierta, Marta met Felipe and María.

I was approaching the chapel, and had stopped by the lagoon to remember the old tales of the Green Monster who lurked there. This man approached me and asked me who I was. I felt very threatened. Before I could decide what to say, he remembered who I was. I could hardly believe it. I was not ready for his warm embrace the moment that I confirmed that I was indeed Pepe's little niece Marta. This was not what I had been told to expect from the family about the ungrateful servants who had denied Marianita entrance to her own house. A rebuke of the family, a sermon on the triumphs of the Revolution, a reminder that this was no longer 'our' Playa Abierta: none of these things would have surprised me. But Felipe's obvious delight at finding me-the only member of Pepe's family he had met since that Christmas of 1958, he told me sadly-stunned me. He remembered the life at Playa Abierta: the order, the excitement and newness of everything, the whizz-bang American technology, the sense of community, the small but regular salaries. It didn't do to cross his employer, that was well known, but if the staff were respectful and worked hard, they would be rewarded. Then suddenly, a million questions about the family: each and everyone, by name. 'And how is Pepe? And Marianita? And Ricardo? And Julito? You must give them a hug for me and tell them we remember them always. We've worried about them, not having heard 
anything for many decades now.' I did not have the heart to tell Felipe that his fond memories were not reciprocated, that the family still held him and the rest of the staff responsible for the loss of their Playa Abierta. Marianita's words-repeated many times in bitter conversations in Miami-rang in my ears: 'Where were they when the house was being taken over by the government? Where was their loyalty?'

Felipe and Maria offered to take me on a tour of Playa Abierta. I had no idea what he meant and was suddenly seized with resentment that he should now pose as the host and me as the guest. Old habits die hard, and the idea that anyone in today's Cuba should offer to 'show me around' Playa Abierta was an affront. But it is hard to maintain the rage when the person before me was so clearly thrilled to see me, and with loving reminiscences of the family flowing out of him as if he really meant them. Felipe disarmed me. With fearful thoughts running through my mind of what my family would think of this encounter, we set off.

It is only in retrospect that I can appreciate fully Felipe's sensitivity that first time. He could have chosen to show me all the new 'improvements' to the place. Instead, he took me on an exclusive tour of my Playa Abierta. We visited only the places he knew would mean something to me: the chapel, the bell, the cave, Elena's house, and from a distance, Pepe's house. He apologised for not taking me to what he knew was the most important site for me. 'No one is allowed to go there unless you're in the military.' Felipe, I've realised since, held two mental maps of Playa Abierta. One was Pepe's and the other was post-Pepe. He knew which Playa Abierta I wanted to see, and which Playa Abierta he should withhold from me.

As I walked around with him, exchanging memories of those three years we had shared there, I was gripped with great sadness: that in Miami our tour would be greeted with derision and contempt. 'Who is this man to be assuming the role of memory-keeper of our Playa Abierta? We are the only custodians of that memory.' I am also conscious of the fact that I am the only one from that Playa Abierta community to have returned. My memories have since come into dialogue with the realities of a place that, whether it remembers us or not, has moved on. I learned this-first with resentment, then with envy-from Felipe's and Maria's tales of their half century of living and working there.

Yet I won't tell my family this. I would not want to be the one to shatter the illusion of those in Miami who still harbour visions of a Playa Abierta awaiting our return: its physical beauty intact, its material environment finally liberated from 'enemy occupation.' Business as usual after an absence of nearly fifty years no longer works for me.

Suddenly, another ambush. Felipe is illustrating the socialist numbering of houses, rather than following the frivolous capitalist custom of giving houses names. 'Look! Sombra. Remember? It's now No. 7 D. 'And from the warm camaraderie of a few seconds before, I go into an unspoken rage. Doesn't Felipe realise what 'Sombra' means to me? Shouldn't he be apologising for what happened to it? Or does he think I no longer care? This rush of raw exile emotions surprised me. Who was feeling this? On whose behalf was I bearing witness to this chance encounter with our old little cottage? Felipe sees Playa Abierta as one integrated whole. Mine, Pepe's, the family's, his, Maria's and everyone else who has lived and loved it over 
the years. I am still the representative of an aggrieved family with no recourse to anything but resentment and anger to appease our sense of loss.

We take the steep road to the left, pass the quarry and keep up the track to the top of the cliff that leads to Pepe's pleasure ground. The stone area is still cleared, though the vegetation is advancing. Felipe takes us past the stone seats and what looks like a wishing well where the path narrows. We turn back to take in the whole of Pepe's vision, the astonishing dazzling light blue of the Florida Straits, the solitary pine tree, the scattered red-roofed houses, the rocky cove, the beach. Pepe's Big House, the architectural marvel and rumoured one time residence of Che Guevara himself, sits snugly on the headland. I am surprised to hear Felipe speak yet again of the Big House and its owner with such warmth. 'Those were wonderful days and we have thought of you all so much through the years.'

That night Felipe offered me the opportunity of renting accommodation in one of Pepe's old cottages, now-like most of Playa Abierta-State-owned. I did not remember it, which was a relief. No memories to haunt me here. It all felt comfortable and secure. Then nightfall, and the bushland turned that deep bottle green of Playa Abierta's nightscape I had forgotten until then. Day tourists come and go, but only close family and friends - our community - had known the secrets of the Playa Abierta of the night. A desperate longing for absent family and friends engulfed me. Another ambush. I did not have the key to connect with that Playa Abierta on my own. My family's Playa Abierta lay buried, layers and layers beneath those bushes, overlaid by almost half a century of a Playa Abierta soil we had neither known nor nourished. But memories don't feed the soil of a loved place. Only being there does.

Felipe and Maria have taught me many things during our on-going conversations about the Playa Abierta that was and has been since we left. One vital thing now occurs to me - a fact they are too gracious to articulate - is that their roots too are buried in that soil. But unlike mine-and my family's - theirs have deepened and widened over fifty years of walking and working and loving that soil. Being there has allowed me to see these things more clearly. But how do I explain that to my family and friends in Miami without sounding like a traitor? They have not been back. They would not understand.

I often wonder about the process of mourning and remembering loved lost places. How different it might have been if we had not lost Playa Abierta to a communist revolution, but to a natural disaster or simply migration to another country. We are not the only ones to have lost and mourned a sacred family site. Dispossessed indigenous peoples know all about that. So do the victims of tsunamis. So do many diasporic groups all over the world. But creating a sense of perspective or, worse, a sense of hierarchy of loss and suffering, is not very useful when inside a particular family's history lies a half-century-old wound that will not heal. And that family history - and that wound - are mine. An earthquake, a planned migration: they also leave wounds, but of a different kind. Ours we blame on particular individualswith human faces and names. It is they who are responsible for our misfortunes. The wound is personal, and so is the hatred.

Indeed, what would the family think of my staying in such a place, an establishment 
that brings dollars to Castro's empty pockets? What would Pepe think? Actually, I know what he-and the family - would think. They would regard this as treason. It is bad enough to have visited Playa Abierta 'under enemy occupation.' But to lend my presence and my dollars to a State enterprise in Playa Abierta is sacrilege of the most grievous kind: I have disgraced the sacred family site by my presence there, and in so doing, the family itself. You see, family honour overrides even patriotism and Cold War politics. Ultimately, it is the only thing left to Cuban exile families to protect and defend at all cost. More than any other visit to Playa Abierta, this most recent visit left me confused and torn. Where do I belong in this war of memories? And who draws the lines of belonging and ownership of a coastline? And for how long? It saddens me that my more recent memories of Playa Abierta will not enrich or enlighten the old family memory album, and in so doing, bring my grieving relatives closer to the complicated realities of Playa Abierta today: that it still belongs to us; that it also belongs to Felipe and Maria; that Playa Abierta both thrives and remembers. We do not need to 'move on' in anger from those memories. Like me, they can always come back and renew their relationship with it again and again. But these are thoughts I keep to myself. Not being allowed to share my experiences of Playa Abierta with the family is part of their imposed punishment on the recalcitrant member who moved to New Zealand.

Pepe died in 1985. He did not want a Christian service, nor to be buried in the family plot in Miami's Woodlawn Cemetery. Instead, he directed that his ashes be scattered unceremoniously in a nearby Florida bay. Who knows why? Pepe loved the sea, and the sea connected him to the island. Perhaps he hoped that his ashes might wash back across the Florida Straits to Playa Abierta.

Marianita is a feisty nonagenerian living in Miami. Exactly how Pepe acquired the funds to buy and develop his paradise is not her concern. Playa Abierta was the pinnacle of her Cuban family happiness. You'll never get to the heart of it. Pointing to a painting of the beach, she says, look at this open beach where no predators threatened, a safe and private life from which no one was excluded. We were not the oppressors, she asserts angrily, everyone was privileged, everyone was happy. But her family no longer toasts 'Next year in Playa Abierta.' When eventually Marta confided to Pepe's boys that she had been back to the Big House, neither cousin appreciated her symbolic reclaiming of their lost paradise. That is man's business. Her gesture was an affront to their dignity and had shamed them.

I too feel shamed by that gesture, if for a different reason. It has taken many years for those emotions to clarify. As I see it now, I did not go to Pepe's house out of love for the old place. I went there for revenge. There were family scores to settle with the usurpers. And once I was in and out, like a man who had helped himself to a woman's body for his momentary pleasure, came the arrogant rush of conquest. 'I 
don't ever have to be here again. Done!' Shedding the political instincts that impelled that first reunion has been a long process. Exorcising the personal shame for violating that precious moment will take much longer. Pepe's house was the heart of my Playa Abierta, my love-place, my safe harbour. Not some chance encounter, to penetrate and then discard.

\section{Reflections 2008}

My visits to Playa Abierta and the reflections they have prompted about things I had long set aside as a New Zealander have both entrenched me in my Cubanness and distanced me from it. They have forced me to re-think my values and my priorities, my sense of fair play and my abiding commitment to my family and the family memories that we share. Honour remains the key to the way I understand human relations. But Playa Abierta — with all its ambushes and complications-has pressed me to re-define what it means. I once thought personal and family honour were one and the same thing. That family honour was personal honour. Sharing with family a sense of what is right and what is wrong was once a reassuring place to be. And until my return visits to Cuba-and Playa Abierta-began a decade ago, my sense of belonging rested comfortably on the knowledge that, despite my physical distance from my family in Miami, these people held my identity and my history. Their values were my values. And if exile had divided us further-I in New Zealand, they in the United States-stronger bonds united us: among them, shared passions and shared hatreds.

I no longer see it that way. Yes, I still hold to the same passions of the little girl who thought Playa Abierta was hers forever and curse the gods who mocked her innocent illusions. But I can no longer justify the hatred of individuals, and hold them responsible for a course of events that has its roots deep in Cuba's long tragic history of political corruption and entrenched disrespect for the most basic human rights: pre-and post-Revolution. It comforts me to think that Playa Abierta will outlive both those passions and those hatreds, that future little Martas will enjoy their moments walking along its beaches, sipping a chilled mango juice and thinking life is beautiful.

Marta's reflections on Playa Abierta remain caught between her loyalty to Pepe and a family that still mourns - and rages — over their lost paradise, and the Felipes and Marías who have dedicated their lives to caring for that same loved place. She wonders how she would feel if the Revolution had fulfilled its promise of returning to 'the people' their land and their dignity. Would she have felt the same urge to storm the barricades of Pepe's house and reclaim it symbolically for her family? Or would she have rejoiced at seeing that splendid coastline now shared equally and freely amongst all Cubans?

The Revolution's betrayal of that promise has made it easier for me to share my family's grief and rage over the loss of our sacred site. Playa Abierta was never intended for 'the people, 'neither during Pepe's time, nor under the Revolution. Where Pepe and his business associates once vacationed in splendour, now military 
officers at one end of the coastline, and wealthy tourists at the other, do likewise. Only the rich and the powerful were-and are-welcome guests to Playa Abierta. Felipe and Maria were never destined to live there, except in the service of those guests. That one brief shining moment that was Playa Abierta of the late 1950s remains intact: both in the child's romantic memory and in the adult's social conscience.

This is more than the story of a contested beach site. This is also the story of an exile family entrenched in memories, passions and hatreds fed and bred since the dawn of that New Year of 1959 when they were set adrift from their futures in a homeland and a sacred site they thought was theirs forever. They will not forgive those they hold responsible for this tragedy. Half a century in exile has only magnified their rage.

To continue to belong to my family demands that I share that rage-or remain silent. I can do neither. But there's a third option. That is why I have changed the names of all the characters and places. Including my own. Including Playa Abierta's. The rest of this story remains, sadly, true. 